\title{
Learning in Australian local government: A roadmap for improving education \& training
}

Commonwealth Journal of Local Governance

Issue 18: December 2015

http://epress.lib.uts.edu.au/ojs/index.php/cjlg

\author{
Ronald Woods \\ Teaching and Research \\ Centre for Local Government \\ University of Technology Sydney
}

\section{Sarah Artist}

Manager Learning Solutions

Local Government NSW

\section{Geraldine O'Connor}

Senior Programmes Officer

Centre for Local Government

University of Technology Sydney
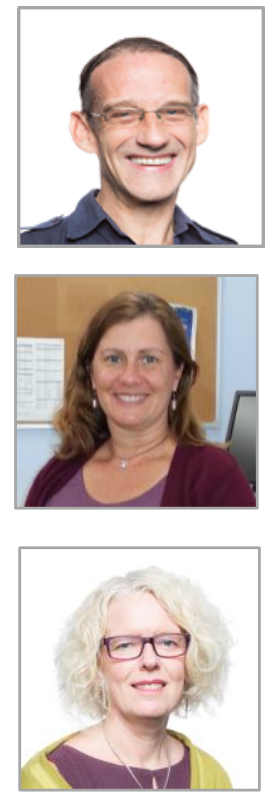

\begin{abstract}
Faced with a context of national and state reform agendas as well as resource scarcity, Australian local government has pressing workforce development issues. This level of government is small in scale, geographically dispersed and subject to variations in state jurisdiction. These factors represent structural constraints to identifying and advocating a national approach for addressing workforce needs such as the provision of tailored education and professional development. This paper documents a sector consultation process exploring education and professional development for local government which aimed to identify needs on both supply and demand sides. The research found that aspirations for education and professional development tailored to the needs of local government aim to support the development of better local governance and leadership, and to address critical skills shortage issues. This may provide empirical grounds for promoting, planning, implementing and evaluating capacity-building initiatives in this third tier of government in the Australian federation.
\end{abstract}

Keywords: Local government, workforce, education and professional development, Australia

\section{Functions of Australian local government}

In contrast to other English-speaking countries such as the United Kingdom and the United States of America, Australia's local government has historically had a relatively narrow range of functions. Initially, it acted as the primary mechanism to transfer to the community the "administrative and financial burden for the provision of basic local services" (Brackerz 2013, p. 5). Services to property

(C) 2015 Ronald Woods, Sarah Artist and Geraldine O'Connor. This is an Open Access article distributed under the terms of the Creative Commons Attribution 4.0 Unported (CC BY 4.0) License (https://creativecommons.org/licenses/by/4.0/), allowing third parties to copy and redistribute the material in any medium or format and to remix, transform, and build upon the material for any purpose, even commercially, provided the original work is properly cited and states its license.

Citation: Commonwealth Journal of Local Governance 2015, 18: 4845, - http://dx.doi.org/10.5130/cjlg.v0i18.4845 
were at the core of its responsibilities, with provision of local roads being the most prominent. ${ }^{1}$ Following the Second World War, local government functions broadened to include town planning and a range of welfare, environmental protection and leisure services.

The past few decades have been marked by an expansion of local government functions and there has been a shift in emphasis away from the traditional focus on 'services to property' towards a more expansive 'services to people' orientation (Dollery et al. 2009, p. 280). This has been partly due to devolution of roles and responsibilities by other spheres of government, but also to market deregulation, industrial relations reform, the privatisation of public utilities, competition policy, technological advancement, and expanding service provision in response to community demands (Brackerz 2013, p. 7).

Local governments in Australia operate under the same legislation and administrative frameworks as apply throughout the states in which they are located, with notionally the same powers and functions. However, since the local government Acts tend to be "permissive rather than prescriptive" (Sansom et al. 2012, p. 15), the larger and better resourced local governments are enabled to take on additional roles. Local government "performs regulatory tasks that would be difficult for a state government to administer because of their localised and varying nature" (Megarrity 2011, p. 2) for example the upkeep of local roads and the preparation of local strategic and land use plans.

A diverse range of roles, responsibilities and activities are required for local government to efficiently and innovatively deliver the range of local services that addresses community and stakeholder needs, and "without an effective local government, local economies and communities would struggle to operate, especially in regional Australia" (LGMA and ACELG 2013, p. 22). Larger local governments can be significant players in metropolitan planning and management, but most are relatively small and lack the capacity to increase their influence. There are no metropolitan-scale councils (such as 'upper-tier' metropolitan or regional governments which comprise a number of smaller municipalities), although South East Queensland, managed by seven large local councils, is regarded as an exception (Sansom et al. 2012, pp. 12-13). In this region, Brisbane City Council, with a population of 1,131,191 (estimated resident population as of June 2013, see Brisbane City Council 2014), is the most populous local government area in the country.

Council amalgamations have often been used as the key policy instrument for improving the efficiency of local government (Dollery et al. 2008), although many councils have also opted for shared service arrangements through partnerships formed between groups of councils (Dollery et al. 2011). The adoption of either approach suggests the need for a wide range of managerial, community engagement and practical skills in order to ensure that service provision proceeds as smoothly as

\footnotetext{
${ }^{1}$ As of 2011, Australia's total road network length was $911,418 \mathrm{~km}$, with local councils being responsible for the majority - approximately 670,000km (Australian Local Government Association [ALGA] 2014).
} 
possible for the citizens concerned. Linked to these structural and other changes has been the growing demand for the greater involvement of citizens - beyond voting in local government elections - in decisions which affect their local areas, and this has inspired councils to explore novel forms of network, consumer and participatory democracy (McKinlay 2012, p. 16).

A notable feature of recent decades has been the shift from 'local government' to 'local governance' (Denters and Rose 2005, p. 9), linked to trends such as increased urbanisation, globalisation and new substantive and participatory demands. Governance implies that public decision-making concerning local issues increasingly involves multi-agency working, partnerships and policy networks which cut across organisational boundaries. In a governance milieu, local governments are taking part in networks that "they cannot easily steer, let alone dominate...[and]...the private sector, the local civil society and individual citizens have a much larger influence than before" (Van den Dool et al. 2010, p. 551).

This shift suggests that the capacity to operate explicitly within a 'governance mode' has become a hallmark of modern local government. New forms of networked governance have been evolving in practice and theory to replace narrow, hierarchical, adversarial and managerial modes that limit the ability of any one level of government, or any single stakeholder, to actively solve the complex problems that communities face (Abbott 2012, pp. 16-8). In keeping with this shift, community consultation, guided by a community engagement strategy, has become an often legislated feature of local government practice, including through the strategic planning that councils pursue (see Tan and Artist 2013).

Local governments in Australia have an increasingly important role in environmental and sustainability implementation, including energy management, natural resource management and recycling (Thomas 2010). They have a role in community development, which includes the planning and provision of community and cultural services, such as; childcare and family support; specialist services to elderly people, people with disabilities, low-income households and young people; and working with indigenous people and organisations (Hornby 2012, pp. 193-300). Local governments have a significant involvement in arts and cultural development and from the early colonial times have been "responsible for the construction of municipal halls, civic centres, performing arts centres, art galleries, libraries and museum buildings, and associated infrastructure" (Hornby 2012, p. 309).

In summary, key functions that are common to local governments throughout the country at the present time, whether as provider, contractor and/or coordinator of services, include services related to:

- engineering and infrastructure, including public works design, construction and maintenance of local roads, bridges and footpaths and drainage; 
- property, including solid waste and recycling;

- administration, regulation and planning, including land use and town planning, development approvals and building inspection;

- environment and health, including catchment management, parks and gardens, public toilets and noise control;

- community and social services, including services for senior citizens, childcare services, youth centres and community housing facilities;

- recreation, culture and education, including community halls, libraries and swimming pools.

(Productivity Commission 2008, p. xx)

\section{Workforce characteristics and challenges}

Each council employs or contracts staff to provide local government services. In keeping with the wide range of local government functions, the work is varied. A study undertaken by Government Skills Australia in 2007 identified around 400 job roles across a typical council, and noted that these can be further broken down into a range of individual job titles (Curry 2010, p. 7). The range of occupations can be classified into four main streams:

- corporate services and governance, including councillor support, finance and customer services;

- engineering and infrastructure, including roads and bridges, waste and sanitation and design and architecture;

- human and community services, including community development, libraries and recreation (including swimming pools);

- planning and environment, including strategic planning, regulatory services and natural resource management.

(LGMA and ACELG 2013, pp. 24-25)

According to the recent Australian Local Government Workforce and Employment Survey (Hastings et al. 2015), local government employs a large and diverse workforce that comprises around $10.2 \%$ of the total public sector. As of 2013, there were 192,500 people working in Australian local government, out of a total of $1.8 \mathrm{~m}$ public sector employees nationally.

Within local government $37 \%$ of employees are aged 50 years or over, compared to the Australian labour force average of $29 \%$. Male employees are on average older than female employees (Hastings et al. 2015). Local government employs a large number of Aboriginal and Torres Strait Islander people: although local government employees represent just over $10 \%$ of the total public service workforce, $22 \%$ of all indigenous public sector workers are employed by local government. 
Employees of local governments have higher levels of educational attainment than the all-industriesworkforce across Australia, with $65 \%$ of men and $70 \%$ of women in local government having a postschool qualification compared to the national average of only 45\% (Hastings et al 2015). In areas where local government has difficulty recruiting staff due to skills shortages, it is also often in competition with other industries for these workers. In recent years, it has been particularly difficult to recruit engineers, planners, childcare staff, environmental health workers, surveyors and managers (Hastings et al 2015). In addition to internal staff, local governments also make use of an external workforce of temporary staff, contractors and volunteers, adding to the complexity of workforce arrangements (McKeown and Lindorff 2011).

Factors such as an ageing workforce, changing technologies and skills shortages have an impact on workforce planning (Freyens 2011; Neville 2012; Tan 2012). For example, changes in population settlement patterns are influential in determining the level and type of services to be delivered by local authorities, and thus the demands for specific skills. In many parts of Australia, councils face challenges in meeting the needs of an ageing population while dealing with the implications of an ageing workforce. In rural and remote areas, staff recruitment and retention can be difficult where populations are decreasing or where there is strong competition for workforce from the mining sector. Building local government's capacity to anticipate and plan for these changes is crucial to ensuring the delivery of efficient and effective services (Tan 2012).

Both elected representatives and local council employees need to have an understanding of the legislative environment as it impacts upon the work of local government, and they preferably also need the skills to track the implications of legislative changes. Except for the Australian Capital Territory, each jurisdiction has a local government Act that provides the rules for the creation and operation of councils, in general covering how councils are elected and determining their powers to make and enforce by-laws or local laws (Productivity Commission 2012, p. 7).

\section{Teaching and learning environment for Australian local government}

The teaching and learning environment for local government in Australia is diverse. This can be linked to the complexity inherent in the local government sector described above, including the wide range of professional, skilled and semi-skilled persons employed internally or externally. Stakeholders and education providers include local councils themselves; local government associations, professional associations and industry skills councils; registered training organisations (RTOs); universities and colleges of technical and further education (TAFE); private sector providers; departments of local government in each jurisdiction; the Department of Education, Employment and Workplace Relations of the Australian Government; and unions. Local government in Australia is not well serviced by the tertiary education sector. Many universities offer a postgraduate programme in some form of government studies (eg public policy or public management), but at the time of the 
inventory in 2010 only four offered postgraduate courses with an explicit focus on local government. This is despite the fact that the sector includes a "complex mix of characteristics and motivations which require specifically tailored solutions" (Artist 2010, pp. 7-8).

Staff activities and the character of each local council are guided by the decisions made by elected councillors (Megarrity 2011, p. 1). There are around 6,600 elected councillors in Australia with an average of just under ten councillors per council (Davy and Brands 2012, p. 9). In keeping with their political function, the role of councillors is to represent their community at council meetings, committees and functions; to communicate local council decisions to the public; to develop council policies; and to make decisions relating to those policies (Megarrity 2011, p. 1), all of which require knowledge and skills that suggest the need for tailored councillor training (Davy and Brands 2012).

\section{Rationale for the 'Learning in Local Government' study}

In order to advance an understanding of education and professional development for Australian local government and identify needs on both supply and demand sides, the Australian Centre of Excellence for Local Government (ACELG) funded a study entitled 'Learning in Local Government' which aimed to explore education and professional development in Australian local government and to put forward an integrated national approach that would reflect the changing operational environment and role of councils. Within the context of the study, conducted from 2010 to 2012, a research team from the University of Technology, Sydney (UTS) Centre for Local Government aimed: to understand the local government sector's needs for essential skills now and into the future; to document the personal needs of people working in the sector for enhanced skills and career development; and to map the pathways between vocational and higher education and ongoing professional development. Key findings and implications from this study are described in this paper, in which the rationale for a focus on education and training is linked to understanding local governments as learning organisations (Örtenblad 2002; Rashman et al. 2009), and to acknowledge the particular features and workforce needs of local government in Australia.

The 'Learning in Local Government' study was undertaken within the context of a perceived lack of data on local government investment in education and training, despite the importance of such investment in light of the pressures on local government to be more efficient and effective. In keeping with conclusions drawn by Rashman et al (2009), the study was seen as research that could help to understand the processes and influences which shape sector-specific features of organisational and inter-organisational learning within the local government sector. The intention was also to generate evidence that would encourage local government to invest more in its current and future workforce, and to find ways to more efficiently address its needs for essential skills in the longer term. 
Research suggests that much organisational learning has tended to be based on performance management and on development programmes orientated towards the individual (Vince and Broussine 2000). Sanderson (2001) points out that a focus on organisational culture is likely to enhance the capacity for longer-term change and improvement. There is a substantial literature advocating the importance to individuals of engaging in lifelong learning to ensure their ongoing employability in the changing world of work; and arguing that organisations need to display a commitment to learning to enable them to face the challenges of globalisation, new technology, market pressures, innovation and survival (Rashman et al 2009, p. 487; Johnston and Hawke 2002, p. 11). Barrados and Mayne (2003, p. 88) argue that there is a need to institutionalise learning processes within public sector organisations, since - as is the case with private organisations - they are expected to value information, to have the ability to learn from the past, and to adapt to changing circumstances.

A learning culture is fostered when employees have an increased capacity to contribute to decisionmaking, and it is also often associated with working with a range of external stakeholders or other partners (Johnston and Hawke 2002, p. 5). In order for organisational changes to endure, managers and employees need to incorporate innovations into their daily routines, and this requires provision of resources to develop new processes and practices, to train employees and to test and experiment with innovations (Fernandez and Rainey 2006, p. 172); it also suggests that training should focus on equipping local government managers to be generalists, so as best to meet the evolving and changing needs of employees (Cox et al. 2010, p. 334).

\section{Methods and data}

The study was funded through the ACELG workforce development programme and was informed by the concurrent development of the national government's workforce strategy, entitled Future-proofing Local Government: National Workforce Strategy 2013-2020 (ACELG 2013).

Data-gathering methods for the 'Learning in Local Government' study comprised:

- attendance at quarterly meetings and annual forums of the ACELG National Workforce Development Reference Group, which represented key local government stakeholders across all jurisdictions;

- a preliminary programme inventory, which was prepared in 2010 in order to profile existing courses relevant to local government (Artist 2010);

- sector consultations, focusing on local government organisations (Artist and O'Connor 2011);

- an online survey, distributed to councils and professional and training organisations throughout Australia, and attracting almost 900 respondents (Artist and O'Connor 2011); 
- a closer examination of the place of e-learning and distance learning in the professional development mix, drawing upon a more detailed analysis of data obtained via the online survey (ACELG 2012);

- a study, based on a review of the literature and interviews with key stakeholders, of the need for training in workforce development and planning, including identifying existing training and capacity-building initiatives for councils (Tan 2012);

- a study on workforce shortages in key skills areas, drawing on labour market data, the ongoing monitoring undertaken by local government sector organisations and data from the National Skills Shortage Strategy 2007 (O’Connor and Artist 2012).

Findings from these several sources are discussed next.

\section{Programme inventory}

The programme inventory included some innovative professional development initiatives which utilise content and modes of delivery tailored to meet the needs of local government, but also identified several difficulties in developing and accessing good education and professional development in local government (Artist and O'Connor 2011, pp. 2-3). Some examples are given here. The speed of change within the operating environment may outpace the time needed to develop and accredit courses. Training budgets have to compete with other resourcing priorities and are often at the discretion of individual managers. Individuals may have a reduced capacity to attend training because of, for example, their need to travel or take time away from work, or because of limited skills in coping with a learning environment. Councils are separated by distance and include small numbers of individuals in multiple professions, reducing the financial feasibility of programme development from a training provider point of view.

Specific gaps identified on the basis of this inventory include local government management skills training, training for elected members, training in disciplines in which skills shortage are being experienced, local government components in mainstream tertiary courses for key professions, training on key policy issues for local government and workforce planning in local government (Artist 2010, pp. 9-12).

\section{Sector consultations}

The aim of the sector consultations was to ascertain what local government organisations in Australia were considered to be key in order to improve education and professional development in local government (Artist and O'Connor 2011, pp. 2-3). The following table was developed at the 2010 ACELG National Local Government Workforce Development Forum to capture reflections and observations made by participants in workshop discussions on issues raised within the sector. 
Table 1: Issues for education and professional development raised in sector consultations

\begin{tabular}{|c|c|}
\hline $\begin{array}{l}\text { Locus of } \\
\text { issue }\end{array}$ & Issues \\
\hline $\begin{array}{l}\text { Within } \\
\text { individual } \\
\text { councils }\end{array}$ & $\begin{array}{l}\text { - Training budgets are scattered across councils, have to compete with other } \\
\text { resourcing priorities and are often at the discretion of individual managers. } \\
\text { - Individuals may lack the capacity or information to clearly define their own } \\
\text { training needs. } \\
\text { - Individuals experience variable levels of access for funds to complete further } \\
\text { education because policies vary across councils. } \\
\text { - Individuals are motivated to undertake qualifications which contribute to job } \\
\text { security and career progression, but these opportunities may not exist in all } \\
\text { councils. } \\
\text { Individuals may have a reduced capacity to attend training because of the } \\
\text { need to travel, take time away from work or because of limited literacy skills. }\end{array}$ \\
\hline $\begin{array}{l}\text { Amongst } \\
\text { training } \\
\text { providers }\end{array}$ & $\begin{array}{l}\text { - Councils are separated by distance and include small numbers of individuals } \\
\text { in multiple professions, which reduces the financial feasibility of programme } \\
\text { development. } \\
\text { - There are significant costs in preparing relevant sector training materials and } \\
\text { a need for experienced practitioners to contribute to the delivery of training. } \\
\text { - There is a lack of facilitated pathways for individuals between RTOs, TAFEs } \\
\text { and tertiary education qualifications. } \\
\text { - The speed of change within the operating environment often outpaces the } \\
\text { time needed to develop and accredit courses. }\end{array}$ \\
\hline $\begin{array}{l}\text { Across the } \\
\text { local } \\
\text { government } \\
\text { sector }\end{array}$ & $\begin{array}{l}\text { - Good training development and provision at a broader scale requires a high } \\
\text { degree of collaboration and significant time commitment. } \\
\text { - There are inconsistencies across the states with regard to accessing federal } \\
\text { funding, and an under-utilisation and lack of knowledge of the vocational } \\
\text { education and training (VET) local government training package. }\end{array}$ \\
\hline
\end{tabular}

\section{Survey}

Respondents to the survey ( $\mathrm{N}=900)$ were all local government employees and councillors. Around three-quarters of the respondents had worked in local government for over five years, and included executive and senior managers, line managers and supervisors, professional officers, administration officers and skilled workers. The survey questions explored respondents' involvement in education and professional development while working in local government, their current level of education, the modes of learning used, the quality of the learning experience, and their desired future educational needs. Key findings from the survey data are described next.

Just over half of all survey respondents had a TAFE Certificate or Diploma, detailed in Table 2.

Table 2: TAFE qualifications of respondents

\begin{tabular}{|l|c|c|c|}
\hline \multicolumn{5}{|l|}{ Respondents with TAFE qualifications } \\
\hline Role/position & Total (\%) & Certificate (\%) & Diploma (\%) \\
\hline Councillor & 42 & 62 & 46 \\
\hline Executive and senior manager & 51 & 55 & 71 \\
\hline Line manager and supervisor & 64 & 75 & 40 \\
\hline Professional & 56 & 74 & 52 \\
\hline Administration & 62 & 85 & 30 \\
\hline Skilled worker & 69 & 82 & 36 \\
\hline
\end{tabular}


Just over half of all the respondents had a university degree, detailed in Table 3.

Table 3: University qualifications

\begin{tabular}{|l|c|c|c|}
\hline \multicolumn{4}{|c|}{ University qualification } \\
\hline Role/position & Total (\%) & Graduate (\%) & Postgraduate (\%) \\
\hline Councillor & 27 & 100 & 50 \\
\hline $\begin{array}{l}\text { Executive and senior } \\
\text { manager }\end{array}$ & 84 & 87 & 57 \\
\hline Line manager and supervisor & 59 & 92 & 55 \\
\hline Professional & 57 & 90 & 52 \\
\hline Administration & 17 & 100 & 18 \\
\hline Skilled worker & 22 & 67 & 44 \\
\hline Summary group & 53 & 90 & 53 \\
\hline
\end{tabular}

Seminars, workshops and conferences (full-day, half-day and one- or two-hour events) were the most commonly utilised mode of professional development across all roles. Only $26 \%$ of respondents had participated in training that occurred over more than two days.

Most of the respondents reported that they make use of written reference material as a source of learning: $68 \%$ of respondents used material distributed by a professional association; $53 \%$ used reference books; and 51\% used material prepared by their councils. The use of material prepared by other councils was lower, with results showing that only $27 \%$ used material prepared by another Australian council, and $10 \%$ had access to material from local governments in other countries.

Just over one-third of respondents had participated in formal work-related mentoring or coaching from someone outside their council, and almost three-quarters rated this experience as 'good' or 'very good'. Major reasons given for these responses were that mentoring can be tailored to individual needs and provides greater insight into personal ways of operating. Participants also liked to be able to bounce around ideas and issues, particularly with someone from outside the organisation.

Distance and online learning had been utilised by almost half of all the respondents, although councillors were an exception in that only $3 \%$ indicated that they had used this form of learning. Distance learning was particularly favoured by those from more remote areas, and respondents also noted that it gave them the ability to balance family and work commitments and flexibility to manage study around their responsibilities. Many noted that self-discipline was required to make effective use of distance learning and that the lack of peer support was sometimes a disadvantage.

Respondents were generally positive about the education and professional development activities in which they had participated. 
Figure 1: Levels of agreement with statements relating to relevance of and satisfaction with education and professional development activities

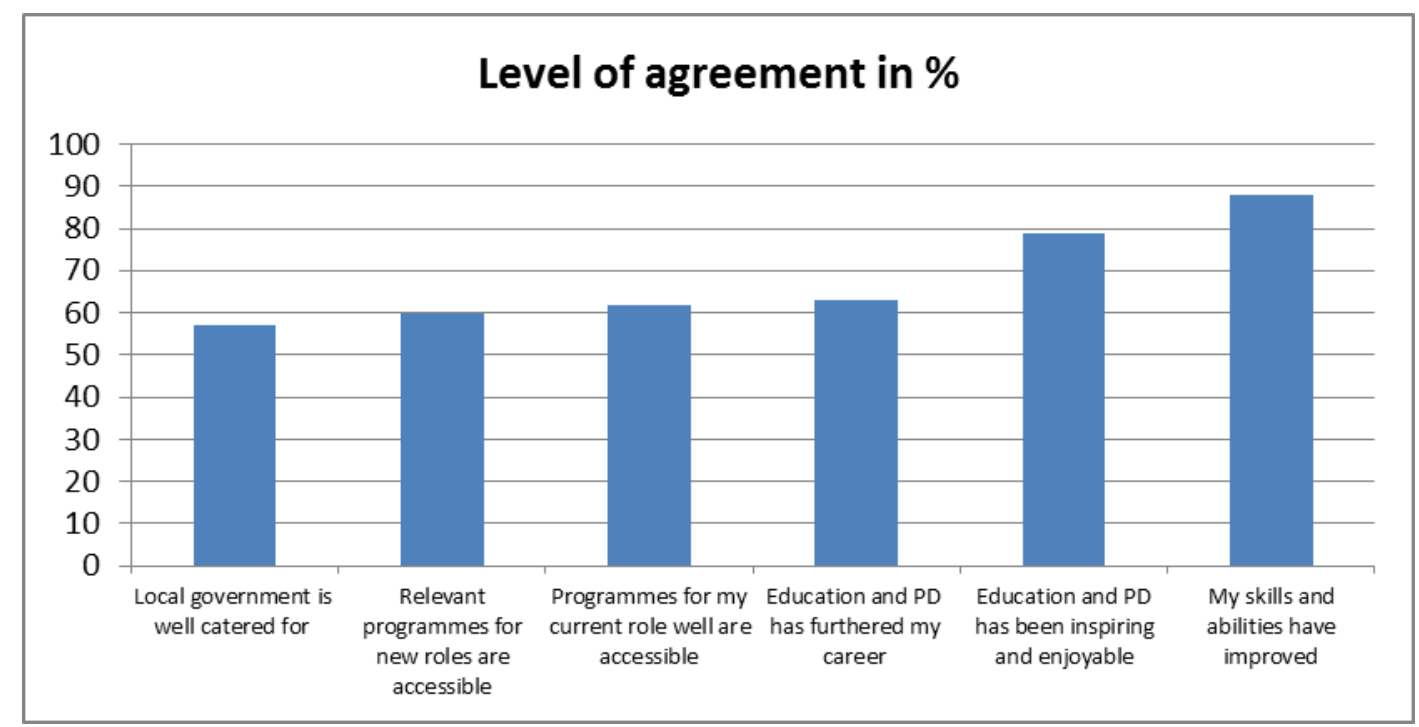

At the same time, they described the following as the major barriers to accessing education and professional development:

Figure 2: Major barriers to accessing education and professional development

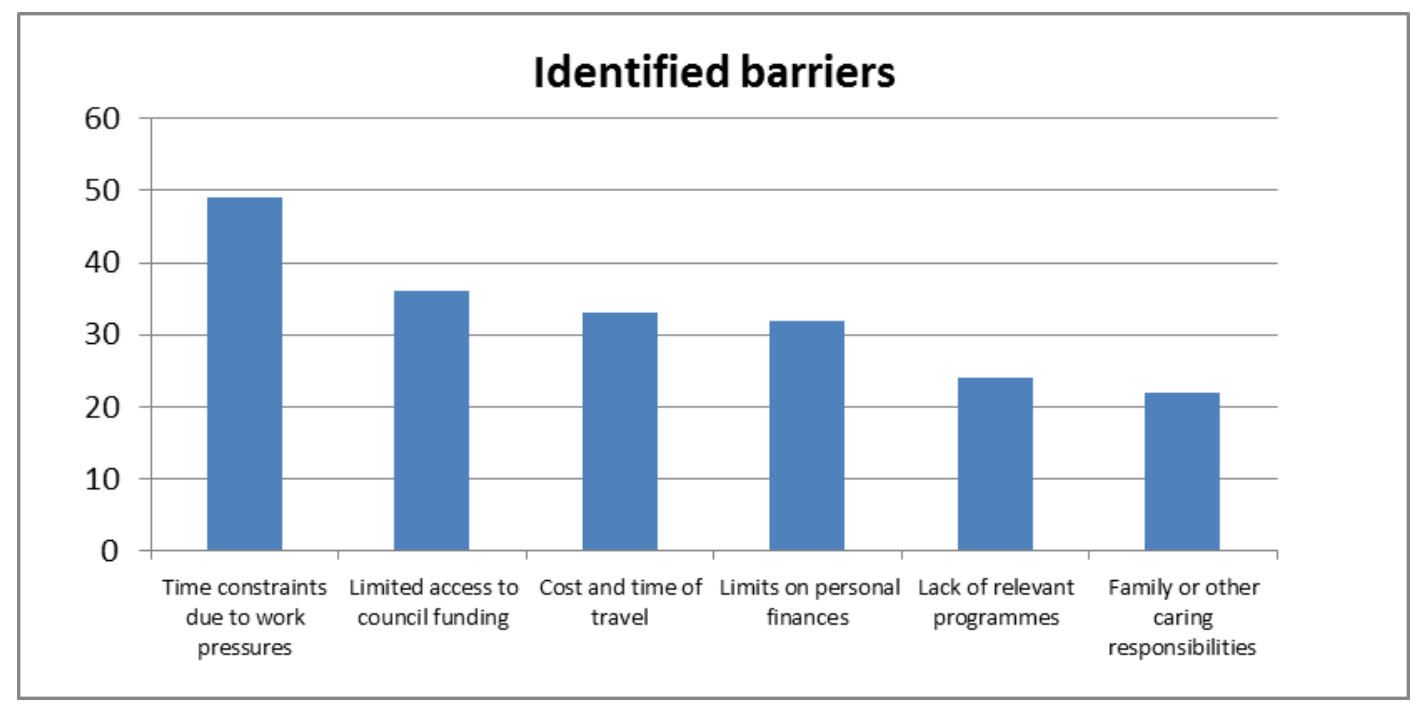

Topics and content that would be useful to respondents are described in Table 4. The results show that the preferred topics and content for education and professional development programmes across all role groups were 'strategy and vision' (73\%), 'community engagement' (72\%) and 'change management' $(67 \%)$. 
Table 4: Education and professional development topics and content deemed most useful by respondents

\begin{tabular}{|c|c|}
\hline Role in local government & Top five topics (in order of preference) \\
\hline Councillors & $\begin{array}{l}\text { Strategy and vision } \\
\text { Community engagement } \\
\text { Asset and infrastructure management } \\
\text { Governance and probity } \\
\text { Financial management }\end{array}$ \\
\hline $\begin{array}{l}\text { Executives and senior } \\
\text { management }\end{array}$ & $\begin{array}{l}\text { Strategy and vision } \\
\text { Change management } \\
\text { Workforce development } \\
\text { Community engagement } \\
\text { Asset and infrastructure management }\end{array}$ \\
\hline $\begin{array}{l}\text { Line managers and } \\
\text { supervisors }\end{array}$ & $\begin{array}{l}\text { Change management } \\
\text { Strategy and vision } \\
\text { Community engagement } \\
\text { Workforce development } \\
\text { Risk management }\end{array}$ \\
\hline Professional & $\begin{array}{l}\text { Strategy and vision } \\
\text { Community engagement } \\
\text { Local government law } \\
\text { Asset and infrastructure management } \\
\text { Risk management }\end{array}$ \\
\hline Administration & $\begin{array}{l}\text { Community engagement } \\
\text { Workforce development } \\
\text { Service delivery options } \\
\text { Change management } \\
\text { Strategy and vision }\end{array}$ \\
\hline $\begin{array}{l}\text { Trades, skilled and outdoor } \\
\text { workers }\end{array}$ & $\begin{array}{l}\text { Community engagement } \\
\text { Service delivery options } \\
\text { Risk management } \\
\text { Councillor-manager relations } \\
\text { Workforce development }\end{array}$ \\
\hline
\end{tabular}

Also in connection with future preferences, $79 \%$ of respondents from all of the different role categories expressed interest in participating in training which provides information about other councils' work and innovations. In addition, $72 \%$ were interested in facilitated problem-solving with peers in other councils and $71 \%$ were interested in exchange opportunities with other councils. These findings suggest that peer learning and good practice exchange would be fruitful methodologies to incorporate in education and professional development programmes for local government.

\section{The place of e-learning and distance learning}

Included in the survey were questions relating to training providers', councils' and learners' use of elearning and distance learning. Almost half of the respondents had utilised e-learning, with $62 \%$ of these rating the experience as 'very good' or 'good' (ACELG 2012). Distance learning was particularly favoured by respondents based in isolated, rural and regional locations, living with physical disabilities or having full-time work, as well as those who needed to balance work and family responsibilities, and those in mobile rather than office-based positions.

E-learning programmes for local government in Australia were found to include web-based modules, units and courses distributed over an intranet or the internet; distance education that leads to formal 
qualifications; webinars (web-based seminars), ie live lectures, workshops or presentations transmitted over the internet; e-mentoring, in which web-based tools, such as emails and chat applications, serve as the primary means of communication between a mentor and mentee; online inductions for employees, contractors or visitors; and blended learning, in which components of a course are offered partly online and partly face-to-face. The value of an e-Learning Portal to support councils was tested. The portal was a web-based platform hosted by ACELG that aimed to bring together a range of resources on e-learning for local government training providers and practitioners. It also served as an online space for the exchange and sharing of ideas, experiences and opinions of elearning in local government. Findings from the study also suggested that local government training providers and councils across Australia are at various phases of implementing e-learning programmes as part of their education and professional development programmes.

The study identified several benefits of and barriers to e-learning (ACELG 2012, pp. 8-14). Benefits included the following:

- e-learning offers personalised learning experiences and enables learners to choose tools and content appropriate to their learning needs, interests and skill levels;

- online delivery of training enables flexibility for individuals to balance their family, work and study commitments, and the delivery time of most online courses is typically shorter than instructor-led training, reducing the time an employee spends away from his/her job;

- the portability of mobile technologies enables learners to access and download content at their own convenience;

- e-learning reduces the costs that may be associated with traditional learning, such as fares, fuel, accommodation and childcare.

At the same time, respondents recognised that e-learning requires learners to have appropriate equipment, a level of competence with the technology, and access to technical support (ACELG 2012). It also requires a level of self-directed motivation and the ability to work unsupervised unmotivated learners with poor study habits may fall behind. There may be high initial costs associated with designing and developing courses, as well as with course and system maintenance and updates. Some learners may miss the interactivity and networking opportunities that come with traditional learning, as well as the opportunity for face-to-face communication with teachers. Other learners may have trouble adapting to a new and unfamiliar mode of education delivery and may feel that e-learning is too theoretical, with online courses easily forgotten (ACELG 2012).

\section{Workforce development and planning}

As a follow-up to the survey, a review was carried out of the need for training in workforce development and planning, including identifying existing training and capacity-building initiatives for 
councils (Tan 2012). Following a review of the literature which identified research and resources available on this subject, selected councils, local government associations, professional institutes, training providers and government agencies responsible for local government in each state and in the Northern Territory were contacted and interviewed about their programmes and activities to strengthen workforce development and planning.

Interview findings provided evidence that there is a lack of strategic importance accorded to workforce planning and development. This is despite the fact that current employees have to update and acquire new skills more frequently during their working lives than did workers from earlier generations. Councils tend to be conservative in their responses to new technologies and there is evidence that they struggle to understand the potential value of technologies such as social media to provide services, to communicate, consult and engage with residents, and to recruit staff. Another challenge that was highlighted by the interviewees was the limited availability of data for councils to plan ahead for workforce needs. This was due not only to the lack of a national minimum dataset for local government, but also the lack of council-specific data of a more qualitative nature. It should be noted that, since the time this survey was carried out, ACELG has conducted a 'Profile of the Australian Local Government Workforce' (Hastings et al. 2015), which draws on the Australian Local Government Workforce and Employment Survey, data from the Australian Bureau of Statistics and other sources such as existing state and territory based workforce surveys. This provides a possible template for the kinds of quantitative data including occupational classifications, gender and age of local government employees, education and training, staff turnover and diversity issues (such as indigenous and disability status) that may be useful for a national dataset. Interviewees noted that useful data would include information on when particular people, especially those in critical roles, plan to retire; career aspirations of staff; family commitments; and staff interest in flexible working arrangements.

\section{Workforce shortages in key skills areas}

The next phase of the 'Learning in Local Government' study focused on workforce shortages in key skills areas. Drawing on labour market data, the ongoing monitoring undertaken by local government sector organisations and data from the National Skills Shortage Strategy 2007, the study explored skills shortages experienced by Australian local governments in the key areas of civil engineering, urban planning, building surveying and environmental health. Opportunities and gaps in education and training in these four areas of skills shortage were explored, and several trends identified (O’Connor and Artist 2012).

One of these trends is difficulty in attracting young professionals to train as environmental health officers and building surveyors, and a particular difficulty in attracting women to train as building surveyors. Also with respect to women in the local government workforce, a contributing issue to the 
skills shortage in urban planning was identified as the ability to retain women in the profession: while equal numbers of men and women graduate as planners, there are around twice as many men as women practising as planners five years after graduation.

Professional organisations work closely with universities nationally to monitor training quality and to encourage the development or adaptation of courses as demand requires. These organisations encourage members to have a bachelor's degree qualification as the minimum training requirement. Education and training approaches should assist in maintaining a balance between knowledge and experience, a crucial issue for each of the skill-shortage professions. Closer alignment between the vocational education and training (VET) and higher education (HE) sectors would contribute to finding this balance. Factors that promote the transition from VET to HE include: enhanced clarity of the relationship between recognised prior learning and the proposed degree; the quality of the VET qualification; ensuring foundation subjects for the degree are covered; and supporting students to be more university-ready. University students undertake work placements as part of their courses. Training undertaken through work experience is an opportunity to support students to complete degrees and gain valuable experience of working within local government.

There is a need to develop more local-government-specific course material in the skills shortage areas, as well as new delivery modes that address the needs of smaller and rural and remote councils. Professional associations and training providers could develop ways of adding material to existing degrees and trade qualifications to meet the sector's training needs. Increased and improved distance learning options can support the local government sector by providing greater flexibility for staff to choose suitable times to undertake training. Mentoring of new and emerging engineers (for example) creates an additional role for engineers who are planning to retire from the workforce and could also be incorporated as part of a workforce retention strategy.

\section{Conclusions and implications}

Local government has undergone significant policy-driven changes in recent decades, but continues to serve and support diverse metropolitan, regional, rural, remote and indigenous communities across Australia. The diversity within the sector is also reflected in access to modes of learning, and the programme inventory and survey undertaken within this study identified these as VET and tertiary qualifications, seminars, workshops, conferences, mentoring, e-learning and written reference material.

While survey participants were positive about their learning experiences - with almost $90 \%$ agreeing with the statement that 'my skills and abilities have improved'; and almost $80 \%$ agreeing that 'education and professional development has been inspiring and enjoyable' - a much lower level of satisfaction was gauged with respect to the degree of suitability of these learning experiences for the 
local government context. Just under 50\% of survey participants felt that local government is not well catered for in education and professional development, and $40 \%$ did not think that 'relevant programmes for doing my current role well are accessible'.

Barriers to accessing education and professional development were identified by participants in sector consultations at individual, council and sector-wide levels. This exploratory study into workforce planning and development suggests that this activity is not accorded high strategic importance. Themes within the literature outlined earlier in this paper which link the capacity to derive evidence from research, evaluation and learning to the capacity to achieve change and improvement, suggest that this lack of focus on workforce development is a factor inhibiting the local government sector from maximising its potential. With almost 200,000 employees and over 6,600 elected members, the unique nature of this sector requires a joined-up approach to develop programmes which facilitate better local leadership and governance.

Australian local government is significant in terms of both function and scale, and quality education and professional development are vital to ensure that the sector continues to respond to the changing needs of local communities, resourcing constraints, pressure from other sectors and skills shortages. Presented with a list of programme development content and topics, survey participants were very interested in areas such 'strategy and vision', 'community engagement', 'governance and probity', 'workforce development' or 'change management'. Their responses point to an appetite and willingness within the sector at all levels to participate in learning opportunities which promote better managerial, leadership and community engagement skills.

The 'Learning in Local Government' study aimed to promote an education and training approach that: is forward-looking and reflects the changing environment and role of local government; focuses equally on all employees across the sector and meets their personal needs to enhance their skills and develop their careers; and promotes seamless pathways between vocational and higher education and ongoing professional development.

Local government needs to be responsive to the needs and desires of its current and potential workforce in order to effectively compete for skilled and talented employees. Demand for workers is increasing, and there is a need to recruit a wide variety of skilled and semi-skilled labour to fully meet the sector's requirements. Taking a national approach to the identification of future learning needs for local government will enable sharing of information about sector needs and programme activities. It will also help to bridge the spatial isolation felt by some local government professionals, as well as improving programme viability by spreading courses more widely. 
In summary, the study suggests the following approaches to future programme development for local government:

- collaborative programmes across jurisdictions and between providers;

- the facilitation of pathways between vocational and higher education;

- the provision of opportunities for peer learning and good practice exchange;

- a more expert use of e-learning on the part of both providers and users;

- training to support better workforce planning within councils;

- priority for initiatives in skills shortage areas.

\section{References}

Abbot, J. (2012) Collaborative governance and metropolitan planning in South East Queensland - 1990 to 2010: From a voluntary to a statutory model. Sydney: ACELG.

Artist, S. (2010) A preliminary inventory and gap analysis of education and professional development for local government in Australia. Learning in Local Government Issues Paper 1. Sydney: ACELG. Available at: http://www.acelg.org.au/file/1542/download [Accessed 4 December 2015].

Artist, S. and O'Connor, G. (2011) An analysis of sector consultations and perspectives on education and professional development. Learning in Local Government Issues Paper 2. Sydney: ACELG. Available at: http://www.acelg.org.au/file/1571/download [Accessed 4 December 2015].

Australian Centre of Excellence for Local Government (ACELG). (2012) eLearning in Local Government. Learning in Local Government issues Paper 3. Sydney: ACELG. Available at: http://www.acelg.org.au/file/1697/download [Accessed 4 December 2015].

Australian Centre of Excellence for Local Government (ACELG). (2013) Future-proofing local government: National workforce strategy 2013-2020. Sydney: ACELG.

Australian Local Government Association (ALGA). (2014) Facts and figures on local government in Australia. Available at: http://alga.asn.au/?ID=59. [Accessed March 2015].

Barrados, M. and Mayne, J. (2003) Can public sector organisations learn? OECD Journal on Budgeting, 3 (3), 87-103. doi: http://dx.doi.org/10.1787/budget-v3-art17-en

Brackerz, N. (2013) Political actor or policy instrument? Governance challenges in Australian local government. Commonwealth Journal of Local Governance, 12, 3-19. doi: http://dx.doi.org/10.5130/cjlg.v12i0.3261

Brisbane City Council. (2014) Brisbane community profiles. Available at: http://www.brisbane.qld.gov.au/about-council/governance-strategy/economic-development/economicdevelopment-program/brisbane-community-profiles [Accessed 4 December 2015].

Cox, R., Gabris, G.T. and. Levin, M.M. (2010) Educating local government managers for the twenty-first century: A preface to the symposium. Journal of Public Affairs Education, 16 (3), 325-336.

Curry, K. (2010) Does support for VET reduce employee churn? A case study in local government. Adelaide: National Centre for Vocational Education Research (NCVER).

Davy, S. and Brands, J. (2012) A national review of training and development for local government councillors. Learning in Local Government Issues Paper 5. Sydney: ACELG. Available at: http://www.acelg.org.au/file/1698/download [Accessed 4 December 2015].

Denters, B. and Rose, L.E. (2005) Local governance in the third millennium: A brave new world? In: B. Denters and L.E. Rose (eds) Comparing local governance: Trends and developments. Houndmills, Basingstoke: Palgrave Macmillan, pp. 1-13.

Dollery, B., Byrnes, J. and Crase, L. (2008) Structural reform in Australian local government. Australian Journal of Political Science, 43 (2), 333-339. doi: http://dx.doi.org/10.1080/10361140802035820 
Dollery, B., Grant, B. and Crase, L. (2011) Love thy neighbour: A social capital approach to local government partnerships. Australian Journal of Public Administration, 70 (2), 156-166. doi: http://dx.doi.org/10.1111/j.1467-8500.2011.00719.x

Dollery, B., O'Keefe, S. and Crase, L. (2009) State oversight models for Australian local government. Economic Papers: A Journal of the Economic Society of Australia, 28 (4), 279-290. doi: http://dx.doi.org/10.1111/j.1759-3441.2010.00047.x

Fernandez, S. and Rainey, H.G. (2006) Managing successful organizational change in the public sector. Public Administration Review, 66 (2), 168-176. doi: http://dx.doi.org/10.1111/j.1540-6210.2006.00570.x

Freyens, B.P. (2011) Managing skills shortages in the Australian public sector: Issues and perspectives. Asia Pacific Journal of Human Resources, 48 (3), 262-286. doi: http://dx.doi.org/10.1177/1038411110368468

Hastings, C., Ryan, R., Gibbs, M. and Lawrie, A. (2015) Profile of the local government workforce 2015 report. Sydney: ACELG, University of Technology, Sydney.

Hornby, F. (2012) Australian local government and community development: From colonial times to the $21^{\text {st }}$ century. Melbourne: Arcadia Scholarly Publishing.

Johnston, R. and Hawke, G. (2002) Case studies of organisations with established learning cultures. Adelaide: National Centre for Vocational Education Research (NCVER).

LGMA (Local Government Managers Australia) and ACELG (Australian Centre of Excellence for Local Government). (2013) Future-proofing local government: National workforce strategy 2013-2020. Available at: http://www.acelg.org.au/national-local-government-workforce-strategy-0. [Accessed March 2015].

McKeown, T. and Lindorff, M. (2011) Temporary staff, contractors, and volunteers: The hidden workforce in Victorian local government. Australian Journal of Public Administration, 70 (2), 185-201. doi: http://dx.doi.org/10.1111/j.1467-8500.2011.00722.x

McKinlay, P. (2012) Building tomorrow's local government: Learning from the global context. Presentation to the Future of Local Government Summit, 27 June 2012. Available at: http://www.mdl.co.nz/site/mckinley/files/Building\%20Tomorrow\%20June\%202012.pdf [Accessed 17 April 2013].

Megarrity, L. (2011) Local government and the Commonwealth: An evolving relationship. Research Paper no. 10 2010-11. Canberra: Parliamentary Library.

Neville, I. (2012) Prospects for the Australian labour market. Presentation given at the $5^{\text {th }}$ National Local Government Workforce Development Forum. Available at: http://www.acelg.org.au/sites/default/files/Ivan\%20Neville\%20\%20Prospects\%20for\%20Aust\%20Labour\%20Market\%20Pv.pdf. [Accessed 4 December 2015].

O’Connor, G. and Artist, S. (2012) A national review of education and training in local government skills shortage areas. Learning in Local Government Issues Paper 6, Sydney: ACELG. Available at: http://www.acelg.org.au/file/1604/download [Accessed 4 December 2015].

Örtenblad, A. (2002) A typology of the idea of learning organization. Management Learning, 33 (2), $213-230$. doi: http://dx.doi.org/10.1177/1350507602332004

Productivity Commission. (2008) Assessing local government revenue raising capacity: Research Report. Canberra: Productivity Commission.

Productivity Commission. (2012) Performance benchmarking of Australian business regulation: Role of local government as regulator. Productivity Commission Research Report Volume 1, Canberra.

Rashman, L., Withers, E. and Hartley, J. (2009) Organizational learning and knowledge in public service organizations: A systematic review of the literature. International Journal of Management Reviews, 11 (4), 463-494. doi: http://dx.doi.org/10.1111/j.1468-2370.2009.00257.x

Sanderson, I. (2001) Performance management, evaluation and learning in 'modern' local government. Public Administration, 79 (2), 297-313. doi: http://dx.doi.org/10.1111/1467-9299.00257

Sansom, G., Dawkins, J. and Tan, S. (2012) The Australian model of metropolitan governance: Insights from Perth and South East Queensland. Sydney: Centre for Local Government, University of Technology. 
Available at: http://www.acelg.org.au/sites/default/files/MetroWorkingPaper2012.pdf [Accessed 4 December 2015].

Tan, S. and Artist, S. (2013) Strategic planning in Australian local government: A comparative analysis of state frameworks. Sydney: ACELG.

Tan, S. (2012) Workforce planning and development: Capacity building opportunities. Learning in Local Government Issues Paper 4. Sydney: ACELG. Available at: http://www.acelg.org.au/file/1700/download [Accessed 4 December 2015].

Thomas, I.G. (2010) Environmental policy and local government in Australia. Local Environment, 15 (2), $121-$ 136. doi: http://dx.doi.org/10.1080/13549830903527647

Van den Dool, L., van Hulst, M. and Schaap, L. (2010) More than a friendly visit: A new strategy for improving local governing capacity. Local Government Studies, 36 (4), 551-568.

doi: http://dx.doi.org/10.1080/03003930.2010.494111

Vince, R. and Broussine, M. (2000) Rethinking organisational learning in local government. Local Government Studies, 26 (1), 15-30. doi: http://dx.doi.org/10.1080/03003930008433975 